\title{
The Effect of Chronic Insulin Therapy on Phosphate Metabolism in Diabetes Mellitus
}

\author{
P. Raskin and C. Y. C. Pak \\ Department Internal Medicine, The University of Texas Health Science Center at Dallas, Texas, USA
}

Summary. Plasma and urine phosphate concentrations were improved in 21 patients with diabetes mellitus during "optimal" metabolic control as compared with "suboptimal" control. During the "suboptimal" control phase the daily insulin dosage averaged $38 \pm$ 22 (SD) U/day and the mean plasma glucose levels averaged $17.1 \pm 1.8 \mathrm{mmol} / \mathrm{l}$, while during the "optimal" control phase the daily insulin dosage averaged $84 \pm 59 \mathrm{U} /$ day and the mean plasma glucose level was $6.2 \pm 1.4 \mathrm{mmol} / \mathrm{l}$. The institution of rigid diabetic control over $4-10$ days significantly raised serum phosphorus from $1.12 \pm 0.16$ to $1.26 \pm$ $0.19 \mathrm{mmol} / 1 \quad(p<0.001)$, and decreased urinary phosphorus excretion from $686 \pm 125$ to $588 \pm$ $88 \mathrm{mg} /$ day $(p<0.001)$. These changes were associated with significant reductions in urinary calcium, urinary glucose, plasma immunoreactive glucagon and serum parathyroid hormone. The diminution in urinary phosphorus loss may have been due to diminished glycosuria but equally could have been influenced by a direct action of insulin on the renal tubule or suppression of glucagon and parathyroid hormone secretion. Under the conditions of this study, reduced urinary phosphorus may have been sufficient to cause a rise in serum phosphorus despite the known effects of insulin on the cellular influx of phosphorus.

Key words: Diabetes mellitus, insulin, phosphorus, parathyroid hormone, glucagon

It is commonly believed that the administration of insulin lowers the circulating concentration of phosphorus by promoting cellular influx from the extracellular fluid $[1,2]$. This effect is particularly apparent during the treatment of diabetic ketoacidosis [2]. However, this action of insulin may be opposed by an effect of insulin on the renal handling of phosphorus, since DeFronzo et al. have shown that the hormone may directly augment the renal tubular reabsorption of phosphorus [3]. Moreover, insulin treatment may secondarily retard phosphorus excretion by suppressing parathyroid function. In a preliminary study [4], we have demonstrated that severe glycosuria in poorly controlled diabetic subjects may be associated with hypercalciuria and possibly with secondary hyperparathyroidism. The institution of rigid diabetic control with insulin produced a correction of the "renal leak" of calcium and a decline in urinary cyclic AMP [5]. Thus, these appear to be two opposing actions of insulin on plasma phosphate, one serving to lower its concentration by transfer into cells, the other tending to raise plasma levels by diminishing renal losses. The purpose of the present study was to examine the effects of improved diabetic control on plasma phosphate, calcium, parathyroid hormone levels and the urinary excretion of calcium and phosphorus.

\section{Methods and Materials}

Twenty-one patients with diabetes mellitus were studied; their clinical characteristics are listed in Table 1. All patients had previously been treated with insulin. All had an endogenous creatinine clearance greater than $80 \mathrm{ml} / \mathrm{min}$. None had a history of pathological skeletal fracture, renal stones, or peptic ulcer disease. All drugs except insulin were withheld during the study. The study was approved by the Human Research Review Committee of the University of Texas Health Science Center at Dallas. Each patient gave informed consent.

The study was conducted at the General Clinical Research Center at Parkland Memorial Hospital for approximately 25 days while the patients consumed a constant metabolic diet, with a daily composition of $400 \mathrm{mg}$ calcium, $800 \mathrm{mg}$ phosphorus, and $100 \mathrm{~mol}$ sodium. Two-sevenths of the total daily calories were given at each meal and one-seventh as a bedtime snack. Caloric intake was sufficient to maintain stable body weight during the study.

The investigation was performed in two phases, an initial phase representing suboptimal insulin therapy with poor control of diabetes, and a subsequent phase of optimal insulin therapy with satisfactory diabetic control. Each phase consisted of 4-7 days of stabilization followed by three study days. During the suboptimal treatment period all patients were hyperglycaemic and had gly- 


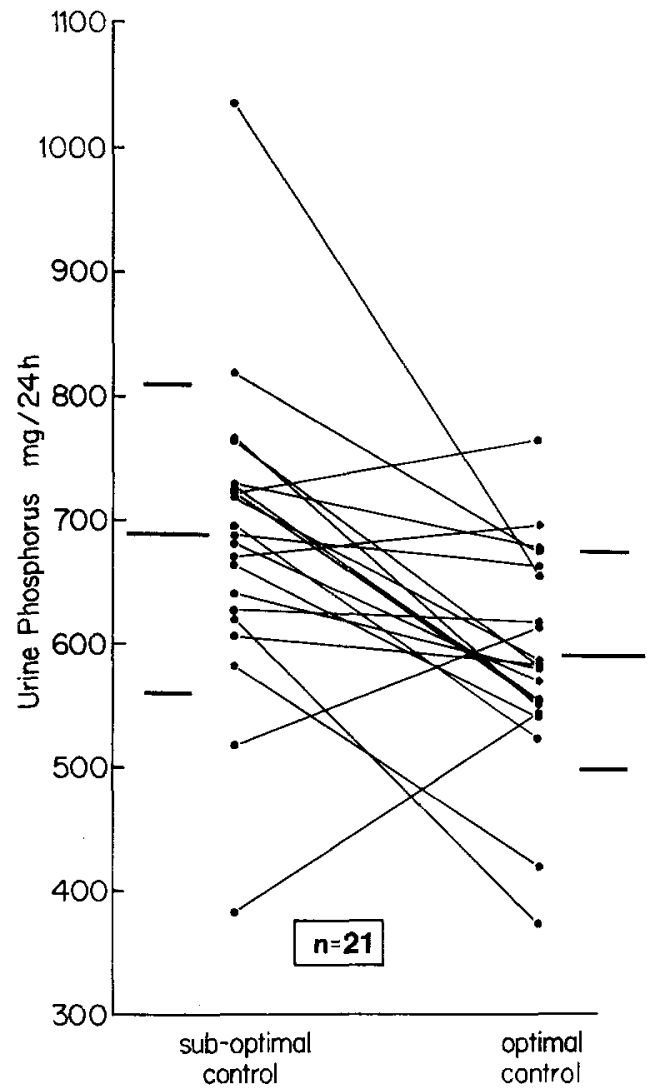

Fig. 1. The effect of chronic insulin therapy on urinary phosphorus excretion in 21 diabetic patients. The horizontal bars represent mean $\pm \mathrm{SD}$

cosuria but none had hyperketonaemia or ketonuria. Plasma bicarbonate was normal in all patients. During the suboptimal treatment phase, all patients were treated with an arbitrarily selected dose of insulin, designed to maintain plasma glucose at approximately $17 \mathrm{mmol} / 1$. After completion of the suboptimal phase, the insulin dose was progressively increased in an attempt to normalise the plasma glucose concentration $(<8.3 \mathrm{mmol} / \mathrm{l})$. Insulin was administered as a combination of neutral protamine Hagedorn (NPH) and regular (soluble) insulin 30 min before breakfast and dinner. Each patient's daily dose of insulin was determined by the glycaemic response to the previous day's insulin dose.

During each of the three days of the study period, daily $24 \mathrm{~h}$ urine collections were made for glucose, calcium, phosphorus, and creatinine estimations. Diabetic regulation was assessed on the basis of plasma glucose determinations made from blood samples obtained five times daily (before each meal and at $03.00 \mathrm{~h}$ ) from an indwelling forearm vein cannula. Plasma samples for measurement of immunoreactive glucagon were obtained simultaneously. The mean plasma glucose and immunoreactive glucagon concentrations for each study period (suboptimal and optimal) were computed from the 15 measurements made during each 3-day period. Fasting morning blood samples were obtained at $08.00 \mathrm{~h}$ at the end of each day's urine collection, for the measurement of calcium, phosphorus and creatinine, and for parathyroid hormone by immunoassay (iPTH).

The endogenous phosphate clearance and creatinine clearance were calculated for each $24 \mathrm{~h}$ period. Tubular reabsorption of phosphorus represented 1-(phosphorus clearance/creatinine clear-

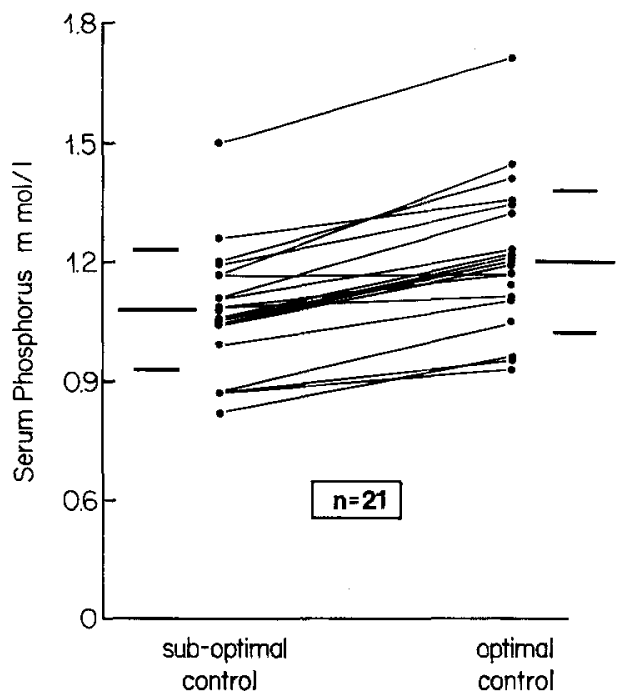

Fig. 2. The effect of insulin therapy on serum phosphorus concentration in 21 diabetic patients. The horizontal bars represent mean \pm SD

ance). The renal threshold phosphorus concentration was calculated from the nomogram of Walton and Bijvoet utilising tubular reabsorption of phosphorus and corresponding serum phosphorus [6].

Glucose in plasma and urine was measured by the glucose oxidase method on the Beckman glucose analyzer. Serum calcium and phosphorus were measured with an autoanalyser, urinary calcium was measured by atomic absorption spectrophotometry, and urinary phosphorus by the method of Fiske and Subbarow [7]. Specimens for immunoreactive glucagon were collected in chilled tubes containing EDTA $12 \mathrm{mg}$ and $1 \mathrm{ml}$ of Trasylol ( $500 \mathrm{kallikrein}$ inhibitor units $/ \mathrm{ml}$ of blood) and centrifuged promptly at $4{ }^{\circ} \mathrm{C}$. Plasma was separated and stored at $-20^{\circ} \mathrm{C}$ until the time of hormone assay. Plasma immunoreactive glucagon was determined by a previously described method using antibody $30 \mathrm{~K}$ [8]. This assay can recognize a difference of $10 \mathrm{pg} / \mathrm{ml}$ with $95 \%$ confidence. Serum iPTH was measured by a modification of a previously described radioimmunoassay $[9,10]$. This assay used an antiserum (Iso-Tex Diagnostic, Friendswood, Texas) directed primarily against the carboxy-terminal region of bovine PTH. Bovine PTH, used as a tracer, was iodinated as previously described. Human PTH (a generous gift of Dr. B. Roos) was used as the standard. The detection limit of this assay was $0.4 \mathrm{ng} / \mathrm{ml}$, with the normal upper limit being $1.9 \mathrm{ng} / \mathrm{ml}$. For each of the various parameters an average value was computed for each 3-day study period, and the values during the suboptimal and optimal insulin treatment periods were compared using Student's t-test for paired samples. Values in results are presented as mean \pm SD.

\section{Results}

During the period of suboptimal diabetic control with insulin, the mean daily dose of insulin was $39 \pm 5$ units/day. The mean plasma glucose concentration was $17.1 \pm 1.8 \mathrm{mmol} / \mathrm{l}$ and glucose excretion averaged $114 \pm 44 \mathrm{~g} /$ day. During the period of optimal diabetic control, the insulin dose averaged $79 \pm 10$ units/day. The mean plasma glucose concentration 
Table 1. Clinical characteristics of diabetic patients

\begin{tabular}{|c|c|c|c|c|c|c|c|c|}
\hline \multirow[t]{2}{*}{ Patient } & \multirow[t]{2}{*}{$\begin{array}{l}\text { Age } \\
\text { (years) }\end{array}$} & \multirow[t]{2}{*}{ Sex } & \multirow[t]{2}{*}{$\begin{array}{l}\% \text { Ideal } \\
\text { body weight }\end{array}$} & \multirow[t]{2}{*}{$\begin{array}{l}\text { Duration of } \\
\text { diabetes } \\
\text { (years) }\end{array}$} & \multicolumn{2}{|c|}{$\begin{array}{l}\text { Insulin dosage } \\
\text { "suboptimal" } \\
\text { period (U/day) }\end{array}$} & \multicolumn{2}{|c|}{$\begin{array}{l}\text { "optimal" } \\
\text { period (U/day) }\end{array}$} \\
\hline & & & & & $\mathrm{am}$ & $\mathrm{pm}$ & am & $\mathrm{pm}$ \\
\hline 1 & 36 & M & 102 & 2 & 33 & 16 & 34 & 19 \\
\hline 2 & 16 & $\mathrm{~F}$ & 103 & 7 & 35 & - & 67 & 27 \\
\hline 3 & 22 & $\mathrm{M}$ & 90 & 5 & 38 & - & 48 & 20 \\
\hline 4 & 32 & M & 102 & 4 & 38 & - & 42 & 25 \\
\hline 5 & 18 & $\mathbf{M}$ & 114 & 10 & 40 & - & 38 & 25 \\
\hline 6 & 17 & $M$ & 85 & 2 & 25 & - & 37 & 11 \\
\hline 7 & 34 & $\mathrm{~F}$ & 92 & 11 & 35 & - & 31 & 16 \\
\hline 8 & 16 & $F$ & 91 & 4 & 42 & - & 52 & 18 \\
\hline 9 & 22 & $\mathrm{~F}$ & 109 & 6 & 35 & 10 & 48 & 17 \\
\hline 10 & 34 & $F$ & 97 & 9 & 32 & - & 45 & 10 \\
\hline 11 & 17 & $F$ & 112 & 6 & 30 & - & 49 & 10 \\
\hline 12 & 28 & $\mathrm{~F}$ & 109 & 5 & 30 & - & 40 & 30 \\
\hline 13 & 37 & $\mathrm{~F}$ & 96 & 15 & 30 & - & 22 & 16 \\
\hline 14 & 30 & M & 94 & 25 & 33 & - & 30 & 19 \\
\hline 15 & 19 & $\mathrm{M}$ & 86 & 5 & 28 & - & 42 & 21 \\
\hline 16 & 23 & $\mathrm{~F}$ & 122 & 5 & 25 & - & 50 & 24 \\
\hline 17 & 41 & $F$ & 166 & 3 & 50 & - & 105 & 45 \\
\hline 18 & 56 & M & 160 & 2 & 25 & - & 90 & 80 \\
\hline 19 & 64 & $\mathrm{~F}$ & 139 & 29 & 5 & - & 24 & 12 \\
\hline 20 & 48 & $\mathrm{~F}$ & 244 & 16 & 100 & 25 & 150 & 70 \\
\hline 21 & 23 & $\mathrm{~F}$ & 135 & 2 & 30 & - & 50 & 15 \\
\hline
\end{tabular}

was $6.2 \pm 1.4 \mathrm{mmol} / \mathrm{l}(p<0.001)$ and glucose excretion fell to $4 \pm 5 \mathrm{~g} /$ day $(p<0.001)$.

During the suboptimal insulin treatment fasting serum phosphorus for the whole group averaged 1.12 $\pm 0.16 \mathrm{mmol} / 1$ and urinary phosphorus excretion averaged $686 \pm 125 \mathrm{mg} /$ day. Improved diabetic control resulted in a significant increase in the serum phosphorus concentration to $1.26 \pm 0.19 \mathrm{mmol} / 1$ $(p<0.001)$. Urinary phosphorus fell significantly to $588 \pm 88 \mathrm{mg} /$ day $(p<0.001$; Fig. 1$)$. Serum phosphorus obtained before breakfast rose in all patients with optimal insulin therapy (Fig. 2). Urinary phosphorus fell in 17 out of 21 patients. The $24 \mathrm{~h}$ phosphorus clearance fell from $13.7 \pm 3.9 \mathrm{mg} / \mathrm{ml}$ in the suboptimal control period to $10.4 \pm 2.5 \mathrm{mg} / \mathrm{ml}(p<$ 0.001 ).

There was a significant increase in both tubular reabsorption of phosphorus (from $87 \pm 3$ to $90 \pm$ $3 \% ; p<0.001)$ and renal threshold phosphorus concentration (from $1.08 \pm 0.22$ to $1.29 \pm 0.21 \mathrm{mmol} / \mathrm{l}$; $p<0.01$ ) with the institution of rigid diabetic control. Urinary calcium excretion averaged $169 \pm$ $65 \mathrm{mg} / 24 \mathrm{~h}$ during the suboptimal insulin treatment period and fell significantly to $118 \pm 58 \mathrm{mg} / 24 \mathrm{~h}$ with optimal insulin treatment $(p<0.001)$. Serum calcium concentration was unchanged by insulin therapy.

During the suboptimal treatment phase, mean plasma immunoreactive glucagon averaged $166 \pm$
$29 \mathrm{pg} / \mathrm{ml}$. With the institution of optimal diabetic control, there was a significant reduction in the mean plasma immunoreactive glucagon to $131 \pm 27 \mathrm{pg} / \mathrm{ml}$ $(p<0.01)$. Values for serum iPTH were not elevated during the suboptimal control phase, averaging 0.80 $\pm 0.38 \mathrm{ng} / \mathrm{ml}$. During optimal insulin treatment, serum iPTH declined slightly to $0.65 \pm 0.30 \mathrm{ng} / \mathrm{ml}$; this change was significant $(p<0.01)$.

\section{Discussion}

The current study clearly shows that the institution of optimal diabetic control over 4-10 days increases the serum concentration of phosphorus and decreases urinary phosphorus excretion. This decrease in urinary phosphorus is probably the result of several factors. First, hyperphosphaturia has long been known to occur with glycosuria and seems to be dependent upon the presence of glucose in the urine. It does not occur with an osmotic diuresis caused by mannitol [11]. The elimination of glycosuria by optimum insulin therapy would tend to attentuate hyperphosphaturia. The second possible explanation is a diminution of the hyperglucagonaemia which is present in poorly controlled diabetes [12]. In the rat, glucagon has been shown to have a direct phosphaturic effect on the renal tubule [13]. In our study plasma glucagon concentration fell with the institu- 
tion of good diabetic control, as shown previously [14]. The resulting decrease in circulating glucagon could have diminished urinary phosphorus excretion.

The third possible explanation involves secondary hyperparathyroidism. During suboptimal insulin therapy, the renal "leak" of calcium associated with glycosuria could have stimulated parathyroid function, and optimal insulin therapy could have reversed the process. This suggestion is supported by our previous finding [4] of reduced renal excretion of calcium and cyclic AMP during optimal therapy. In the present study, a significant decline in urinary calcium was also shown. Moreover, serum iPTH declined significantly during optimal insulin treatment. It is unlikely that this explanation could have accounted for all of the reduction in urinary phosphorus, in so far as the change in serum iPTH levels was small.

Finally, decreased phosphorus excretion might have resulted from a direct effect of insulin on the renal tubule. DeFronzo et al. [3] have shown in human subjects that the infusion of insulin sufficient to maintain plasma insulin concentration within the normal range, significantly lowered urinary phosphorus. The diminution in urinary phosphorus excretion, produced by direct and indirect actions of insulin described above, must be principally renal in origin, since phosphorus clearance decreased and tubular reabsorption of phosphorus and renal threshold phosphorus concentration increased significantly, despite a rise in the filtered load of phosphorus. The results suggest that this reduced renal excretion of phosphorus may have caused the increase in serum phosphorus concentration.

The finding of the increased circulating concentration of phosphorus encountered during optimal insulin therapy is paradoxical since insulin itself has been shown to cause a shift of phosphorus from the extracellular space to the intracellular space $[1,2]$. If this action of insulin on cellular flux of phosphorus were the only mechanism, one would have anticipated a fall in serum phosphorus concentration. The data indicate that the renal effects of insulin with respect to phosphorus transport may have predominated over its action on cellular phosphorus fluxes under the particular conditions of this experiment.

In conclusion, the balance between the action of insulin on renal handling of phosphorus and on cellular flux of phosphorus probably determines directional changes in serum phosphorus concentration. Under steady-state conditions, optimal insulin treatment increases serum phosphorus by reducing phosphorus excretion. It is of interest that Gertner et al. [5] reached essentially identical conclusions on the basis of studies in a smaller number of diabetic patients.
Acknowledgements. The authors would like to acknowledge Dr. Daniel W. Foster for his advice and consultation; Marilyn Alford, R. N., and Suzanne Strowig, R.N. who were invaluable in the completion of this study. We also wish to thank Allen Stewart, Rusty Nicar, David Brown, and Scott Sismilich for their technical help, Mrs. Bette Newton for her aid in preparing the manuscript, and the nurses and staff of the General Clinical Research Center for the care of our patients.

Supported by NIH grants 2-R01-AM18179; 1-M01RR00633; 5-R01-AM16061, and grants from the American Diabetes Association, North Texas affiliate, and the American Heart Association.

\section{References}

1. Kay DH, Robison R (1924) Effect of insulin administration on the distribution of the phosphorus compounds of blood and muscle. Biochem J 18: 1139-1143

2. Franks M, Berris RF, Kaplan NO, Myers GB (1948) Metabolic studies in diabetic acidosis. Arch Int Med 81: 42-55

3. DeFronzo RA, Cooke CR, Andres R, Faloona GR, Davis PJ (1975) The effect of insulin on renal handing of sodium, potassium, calcium, and phosphate in man. J Clin Invest 55: 845-855

4. Raskin P, Stevenson RM, Barilla DE, Pak CY (1978) The hypercalciuria of diabetes mellitus: its amelioration with insulin. Clin Endocrinol 9: 329-335

5. Gertner JM, Tamborlane WV, Horst RL, Sherwin RS, Felig P, Genel M (1980) Mineral metabolism in diabetes mellitus: changes in accompanying treatment with a portable subcutaneous insulin infusion system. $\mathrm{J}$ Clin Endocrinol Metab 50: $862-866$

6. Walton RJ, Bijvoet OLM (1975) Nomogram for derivation of renal threshold phosphate concentration. Lancet 2: 309-310

7. Fiske CH, Subbarow Y (1925) The colorimetric determination of phosphorus. J Biol Chem 66: 375-400

8. Faloona GR, Unger RH (1974) Glucagon. In: Jaffe BM, Behrman HR (eds) Methods of hormone radioimmunoassay. Academic Press, New York, pp 317-330

9. Pak CYC, Fetner C, Townsend J, Brinkley L, Northcutt C, Barilla DE, Kadesky M, Peters P (1978) Evaluation of calcium urolithiasis in ambulatory patients: comparison of results with those of inpatient evaluation. Am J Med 64: 979-987

10. Arnaud CD, Tsao HS, Littledike T (1971) Radioimmunoassay of human parathyroid hormone in serum. J Clin Invest 50: 21-34

11. Massry SG, Friedler RM, Coburn JW (1973) Excretion of phosphate and calcium. Arch Intern Med 131: 828-859

12. Unger RH (1976) Diabetes and the alpha cell. (Banting Memorial Lecture) Diabetes 25: 136-151

13. Butlen D, Jard S (1972) Renal handling of $3^{\prime} 5^{\prime}$-cyclic AMP in the rat. The possible role of luminal $3^{\prime} 5^{\prime}$-cyclic AMP in tubular reabsorption of phosphate. Pflueger's Arch 331: 172-190

14. Raskin P, Unger RH (1978) Effect of insulin therapy on the profiles of plasma immunoreactive glucagon in juvenile-type and adult-type diabetics. Diabetes 27: 411-419

Received: 27 June 1980

and in revised form: 24 January 1981

Dr. P. Raskin

Department of Internal Medicine

University of Texas Health Science Center at Dallas

5323 Harry Hines Boulevard

Dallas, Texas 75235, USA 